\title{
Elaboration of carbonated beverages from wheatgrass
}

\author{
Elaboración de bebida carbonatada a partir trigo \\ Nelson Loyola López ${ }^{*}$, Carlos Acuña Carrascoํ, Luis Córdova Rivera ${ }^{1}$, \\ Sebastian Guzmán Torres ${ }^{1}$, Mariela Arriola Herrera ${ }^{1}$
}

\begin{abstract}
A carbonated beverage from organic wheat herb was elaborated. Wheat was grown in $22 \times 17 \mathrm{~cm}$ plastic trays with $25 \mathrm{~g}$ seed per tray. Wheat was harvested on the tenth day after sprouting. Seven treatments were carried: $\mathrm{T}_{0}$ control; wheatgrass juice, $\mathrm{T}_{1}$ clarified wheatgrass juice, with $\mathrm{CO}_{2}, \mathrm{~T}_{2}$ wheatgrass juice, non-clarified, with $\mathrm{CO}_{2}, \mathrm{~T}_{3}$ clarified wheatgrass juice, with stevia, $\mathrm{T}_{4}$ wheatgrass juice, non-clarified, with stevia, $\mathrm{T}_{5}$ clarified wheatgrass juice, with $\mathrm{CO}_{2}$ and stevia, $\mathrm{T}_{6}$ wheatgrass juice, non-clarified, with $\mathrm{CO}_{2}$ and stevia. Chemical, nutritional and sensorial analyzes of the juice were performed between days 0,30 and 90 , soluble solids ( ${ }^{\circ}$ Brix), $\mathrm{pH}$, acidity $(\%)$, ascorbic acid ( $\left.\mathrm{mg} / 100 \mathrm{~g}\right)$, reducing sugars and attributes; color, aroma, taste and acceptability were determined. The beverages elaborated with and without clarification from wheatgrass juice plus stevia with $\mathrm{CO}_{2}$, showed similar content of vitamin $\mathrm{C}$, acidity and $\mathrm{pH}$, with similar perception of the sensorial attributes color, aroma and flavor and an equal degree of acceptability. Beverages of treatment $\mathrm{T}_{5}$ and $\mathrm{T}_{6}$ had significantly different contents of ${ }^{\circ}$ Brix and reducing sugars. The most probable number of total coliforms and Escherichia coli was less than the range allowed by the sanitary regulation of food.

Keywords: Beverages, Wheat, wheatgrass, clarified, $\mathrm{CO}_{2}$, stevia, evaluation.
\end{abstract}

\section{RESUMEN}

El trigo fue cultivado en bandejas de plástico de $22 \times 17 \mathrm{~cm}$, con una dosis de siembra de $25 \mathrm{~g}$ por bandeja. Se cosechó al décimo día después de la brotación. El estudio consistió en siete tratamientos: T0 testigo, jugo de hierba de trigo; T1 jugo de hierba de trigo clarificado, con CO2; T2 jugo de hierba de trigo, sin clarificar, con CO2; T3 jugo de hierba de trigo clarificado, con stevia; T4 jugo de hierba de trigo, sin clarificar, con stevia; T5 jugo de hierba de trigo, sin clarificar, con CO2 y stevia; T6 jugo de hierba de trigo, sin clarificar, con CO2 y stevia. Se realizaron análisis químicos, nutricionales y sensoriales del producto obtenido, una vez almacenada la bebida a los 0,30 y 90 días. Se determinaron los sólidos solubles ( ${ }^{\circ}$ Brix), el pH, acidez (\%), ácido ascórbico (mg $/$ $100 \mathrm{~g}$ ), azúcares reductores y atributos; así como el color, aroma, sabor y aceptabilidad. También se realizó un recuento de coliformes totales y Escherichia coli. Las bebidas con y sin clarificación del jugo de pasto de trigo más stevia con CO2 mostraron un contenido similar de vitamina $C$, acidez, $\mathrm{pH}$ y de percepción de atributos sensoriales de color, aroma y sabor, y un grado igual de aceptabilidad. Los tratamientos T5 y T6, tuvieron contenidos significativamente diferentes de ${ }^{\circ}$ Brix y azúcares reductores. El número de coliformes totales y Escherichia coli fue menor al rango permitido por el reglamento sanitario de los alimentos.

Palabras clave: bebidas, trigo, clarificado, pasto de trigo, CO2, stevia, evaluación.

\section{Introduction}

The wheat plant is an annual monocotyledon one, belonging to the Poaceae family and to Triticum genre, which is classified within the Triticeae group. Wheat has a dense and fasciculated root, which rises from the crown and branches up to about $30 \mathrm{~cm}$, which can deepen more than $150 \mathrm{~cm}$, depending on the type of soil. (Moreno et al., 2001). Wheatgrass juice is an aqueous form of the plant that is produced by pressing the young shoots and it is commercially available in liquid forms, powders or concentrates, and can be consumed by itself, or mixed with fruit juices (Wakeham, 2013). Although carbonated beverages are products not recommended by physicians, their consumption increases year by year, being related to a high rate of obesity and cardiovascular risks, both in adults and children (Zapata, 2011). Refreshments constitute a commodity, being the carbonated beverages the

1 Universidad Católica del Maule. Facultad de Ciencias Agrarias y Forestales. Departamento de Ciencias Agrarias. Camino a Los Niches S/N, Km 6, Curicó, Chile.

* Autor de correspondencia: mailto: nloyola@ucm.cl; nloyola@ucm.cl.

Fecha de Recepción: 4 de Noviembre, 2019.

Fecha de Aceptación: 15 de Enero, 2020. 
third most important product in the food basket of a Chilean family, locating Chile in the third country with the highest per capita consumption of soft drinks, preceded by Mexico and the United States (Instituto de Políticas Públicas en Salud IPSUSS, 2019).

This research was carried out with resources from the Integrated Platform Project to promote the commercialization of processed agricultural products and rural tourism services from Maule small producers, "Vitrina Campesina", BIP Code 30136476-0, financed by the Innovation Fund for Regional Competitiveness, FIC-R, from the Regional Government of Maule, Chile, and developed by the Catholic University of Maule. In order to solve the problem, the following hypothesis has been drawn: the addition of stevia $+\mathrm{CO} 2$ will allow obtaining a carbonated beverage with nutritional and sensorial valuation from the wheatgrass juice with and without clarification. As a general objective, this work is aimed at evaluating the nutritional and sensorial evaluation of a beverage from wheatgrass juice with stevia added, with and without clarification.

As specific objectives: to evaluate in the elaborated beverages chemical parameters such as soluble solids, $\mathrm{pH}$ and acidity; to evaluate the nutritional content expressed in vitamin $\mathrm{C}$ and reducing sugars of the beverages obtained; to evaluate sensorial attributes from wheatgrass juice with and without clarification, with $\mathrm{CO}_{2}$ injection, expressed in color, aroma, flavor and its acceptability by the panelists; to evaluate total coliforms and Escherichia coli in the elaborated carbonated beverages from wheatgrass juice.

\section{Materials and methods}

The cultivation was carried out in the Lingues sector, near San Fernando, O'Higgins region, Chile, whose coordinates are south latitude $34^{\circ} 32$ ' $34^{\prime \prime}$, west longitude $70^{\circ} 54^{\prime} 39^{\prime \prime}$. Lingues is located $15 \mathrm{~km}$ N.E. of San Fernando city, which is characterized by average temperatures between $4.2^{\circ} \mathrm{C}$ minimum in July, and $28.9^{\circ} \mathrm{C}$ as the maximum temperature in January. On the other hand, its water regime is around $753 \mathrm{~mL}$ a year (Santibáñez and Uribe, 1993). For the cultivation of the plant material, three key inputs were needed: organic seeds, which were acquired through www.broteschile.cl website. A substrate of good quality for optimal germination, which is composed of a sand-leaf soil: humus in a relationship (2:1:1). The plant material was hydrated daily. It is important to mention that it was located in plastic trays of $22 \times 17 \mathrm{~cm}$.

The research was carried out in the laboratory of Sciences, belonging to the Catholic University of Maule, San Isidro Campus, near Curicó city, Maule, Chile. The Campus is located near kilometer 6, on the way to Los Niches, west of Curicó city, being its coordinates south latitude $35^{\circ} 5$ ' 35.8002 , west length $71^{\circ}$ 8' 1.9998" (Santibáñez and Uribe, 1993). A trial with wheatgrass juice or wheatgrass was carried out, being the nutritional content of the beverage evaluated, and expressed in vitamin $\mathrm{C}$ and reducing sugars. Chemical analyzes; soluble solids, $\mathrm{pH}$, acidity and their sensorial evaluation: color, aroma, taste and acceptability. Seven treatments were performed in the test, with 3 repetitions of each of them; each treatment had a particular variable (Table 1). The development of beverages from the juice obtained from the milling of wheat plants was carried out with and without clarification, bringing about two products which are schematically represented in the flow line (Figure 1).

The ${ }^{\circ}$ Brix that the samples of carbonated beverages of wheatgrass presented was determined. The procedure was performed according to Official Methods of Analysis, AOAC (AOAC, 1990).

$$
\text { VITAMIN C }(\mathrm{mg} \%)=
$$

$8 \mathrm{x}$ volume used in standardization $\mathrm{x} 100$

Volume used of juice diluted $\mathrm{x}^{\circ}$ Brix diluted juice $\mathrm{pH}$ was determined according to A.A.C.O. (1990), and the results were expressed as\% prevailing acid. The procedure was performed according to AOAC (AOAC, 1990).

The calculation to obtain titratable acidity was as follows:

$$
\text { Acid } \%=\frac{V \times N \times F \times 100}{M}
$$

Where: V: spent volume of $\mathrm{NaOH} \mathrm{N}$ : Normal $\mathrm{NaOH} F$ : predominant acid factor M: grams of sample (Table 2).

The quantitative determination of reducing and total sugars was performed by Lane and Eynon method AOAC, 1990. The above reactions were standardized with a Fehling solution. With regards 
Table 1. Treatments to evaluate.

\begin{tabular}{cl}
\hline Treatment & \multicolumn{1}{c}{ Description } \\
\hline $\mathrm{T}_{0}$ & Witness Treatment; wheatgrass juice. \\
$\mathrm{T}_{1}$ & Clarified wheatgrass juice, with a $\mathrm{CO}_{2}$ injection. \\
$\mathrm{T}_{2}$ & Non-clarified wheatgrass juice, with $\mathrm{CO}_{2}$ injection. \\
$\mathrm{T}_{3}$ & Clarified wheatgrass juice, with stevia added. \\
$\mathrm{T}_{4}$ & Non-clarified wheatgrass juice, with stevia added. \\
$\mathrm{T}_{5}$ & Clarified wheatgrass juice, with stevia added and \\
& a CO injection. \\
$\mathrm{T}_{6}$ & Non-clarified wheatgrass juice, with stevia added \\
& and a $\mathrm{CO}_{2}$ injection. \\
\hline
\end{tabular}

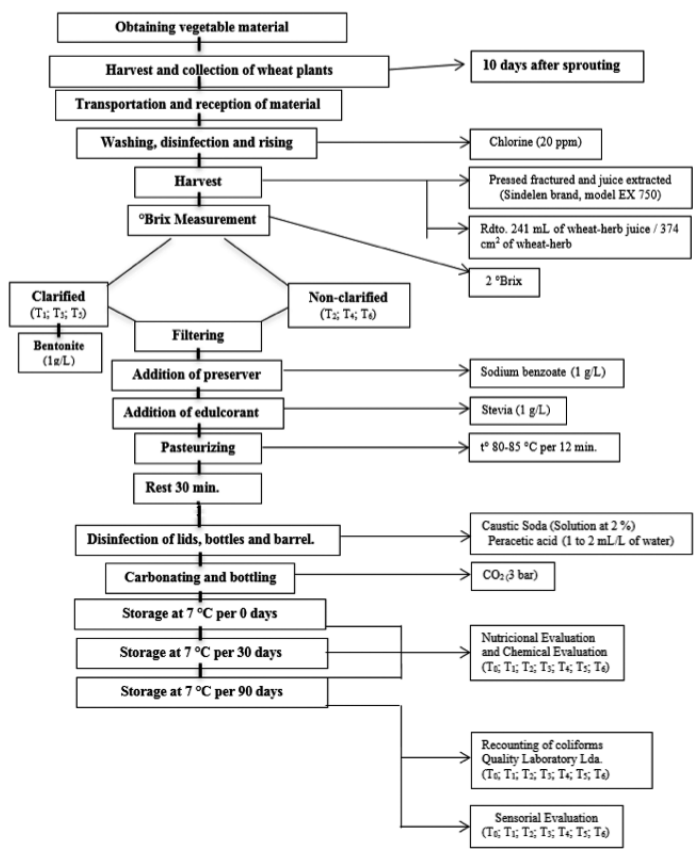

Figure 1. Clarified and non-clarified wheat beverage processing flow.

Source: AOAC, 1990.

to the preparation of the clarified sugar solution, it was carried out according to the AOAC (AOAC, 1990) adaptation, as well as the determination of the reducing sugars (originally present). For this purpose, the following formulas and calculations were used:

$$
\% \text { of reducing sugars }=\frac{V 1 \times F}{W m \times G} \times 100
$$

Where: V1: total volume (100 mL) F: Fehling factor (0.041) Wm: sample weight G: Solution spent in $\mathrm{mL}$.
Table 2. Predominant acids.

\begin{tabular}{ll}
\hline \multicolumn{1}{c}{ Type of acid } & Factor \\
\hline Citric Acid & 0.064 \\
Malic Acid & 0.067 \\
Citric Acid Anhydrous & 0.064 \\
Citric Acid Hydrated & 0.070 \\
Ascorbic Acid & 0.088 \\
Tartaric Acid & 0.075 \\
Acetic Acid & 0.060 \\
Lactic Acid & 0.090 \\
\hline
\end{tabular}

Source. AOAC, 1990.

Regarding the microbiological test, they were carried out at 90 days of storage, where Escherichia coli and total coliforms were the microorganisms evaluated.

\section{Sensorial analysis}

After the preparation of the beverage from wheat grass, and after 90 days of storage, a sensorial analysis was performed with 13 trained panelists, who evaluated 3 random samples of each treatment, measuring the organoleptic attributes of aroma and flavor in an unstructured hedonistic primer, according to a scale from 0 to $13 \mathrm{~cm}$ from left to right (adapted from Hernández, 2005). A color evaluation was performed using color primers with a value of 1 to 6 . The acceptability of the product was measured on a scale of values from 1 to 9 , where number 1 meant "I extremely dislike it" and the number 9 "I like extremely it" (adapted from Ministerio de Salud de Chile, 2015; adapted from Munsell, 1994).

\section{Experimental design}

In the present study, two experimental designs were carried out, in which treatments were randomly and uniformly assigned so as not to influence on the results. The selected experimental unit was $120 \mathrm{~mL}$ contained in a bottle. A completely random block design (DBCA) was used for chemical and nutritional determination. The block used in this trial was with the 3 storage times of the wheatgrass juice; 0 days, 30 days and 90 days, in 7 treatments. The data obtained in the nutritional and chemical tests were analyzed with a confidential level of 95\%. In cases where significant differences were 
found, they were submitted to the Tukey test with a significance level of 0.05 .

The sensorial analysis was performed through a comparison to evaluate the sensorial attributes of the beverages, according to the treatments applied, for this aim, a completely randomized experimental design (CRED) was used, with 7 treatments and 3 repetitions of each of them, measured at 90 days of storage. In cases where significant differences were found, they were submitted to the Tukey test, with a level of significance of 0.05 . Data was analyzed with the statistical program IBM-SPSS, Statistics version 22, (2013). This research was carried out with resources from the Integrated Platform project to promote the commercialization of processed agricultural products and services of rural tourism of small producers from Maule, "Vitrina Campesina" (BIP Code 30136476-0, financed by the Innovation Fund for Regional Competitiveness, IFR-C, from the Regional Government of Maule, and carried out by the Catholic University of Maule.

\section{Results and Discussion}

\section{Chemical analysis}

\section{Soluble solids}

Soluble solids found in clarified and non-clarified beverages had a degree of dispersion (data not shown). The contents of soluble solids showed their minimum value $\left(0.2^{\circ} \mathrm{Brix}\right)$ in beverages made in the control treatment $\left(\mathrm{T}_{0}\right)$, which remained constant in the three moments of evaluation. However, the maximum content of soluble solids $\left(0.6^{\circ} \mathrm{Brix}\right)$ was present in the clarified beverages belonging to treatments $\left(T_{3}\right.$ and $\mathrm{T}_{5}$ ), and the non-clarified beverages belonging to treatments $\left(\mathrm{T}_{4}\right.$ and $\left.\mathrm{T}_{6}\right)$, which occurred on days 0 and 30 of storage. At day 90 , there was a decrease in the concentration of soluble solids in the nonclarified beverages belonging to treatments $\left(T_{4}\right.$ and $\mathrm{T}_{6}$ ). The elaboration of the beverages under the different treatments, together with the storage time frozen at $7{ }^{\circ} \mathrm{C}$, caused significant differences on the evaluation of soluble solids (p-value 0.000 ); this was due to the following reasons: $\left(\mathrm{T}_{0}\right)$ the clarified beverages belonging to treatment $\left(\mathrm{T}_{1}\right)$ and the non-clarified beverages belonging to treatment $\left(\mathrm{T}_{2}\right)$ did not show the addition of stevia sweetener in its composition; in contrast with beverages made in the control treatment $\left(\mathrm{T}_{0}\right)$, the clarified beverages belonging to treatments $\left(\mathrm{T}_{3}\right.$ and $\left.\mathrm{T}_{5}\right)$ and the nonclarified ones belonging to treatments $\left(\mathrm{T}_{4}\right.$ and $\left.\mathrm{T}_{6}\right)$, which showed the addition of stevia sweetener. Regarding the content of soluble solids, there was a significant difference between the juices prepared with and without clarification. This difference was due to treatments $\left(\mathrm{T}_{3}, \mathrm{~T}_{5}\right)$ in the clarified ones and to treatments $\left(\mathrm{T}_{4}, \mathrm{~T}_{6}\right)$ in the non-clarified ones, which were shown mainly at day 90 of storage. In the work written by Hasani and Kongoli (s.a), they obtained soluble solids values of $3.5^{\circ}$ Brix, using a refractometer to measure wheatgrass juice at $100 \%$ concentration. The highest value obtained in this trial was $0.6^{\circ}$ Brix, being the main reason that the wheatgrass juice was diluted in water in a 2:1 relationship (Water: wheatgrass juice).

\section{pH}

The $\mathrm{pH}$ found in the clarified and non-clarified beverages showed a degree of dispersion (data not shown). The $\mathrm{pH}$ values showed their minimum value (4.7) for the clarified beverages belonging to treatment $\left(\mathrm{T}_{3}\right)$, at 30 days of storage. However, the highest value (6.4) was obtained from beverages made with the control treatment $\left(\mathrm{T}_{0}\right)$ at 90 days. It was also observed that in all treatments there was a slight increase in $\mathrm{pH}$ at 90 days of storage. Statistical analysis showed that the elaboration of the beverages in the different treatments, plus the storage time, caused a statistically significant effect (p-value 0,000$)$ on the $\mathrm{pH}$ level.

Regarding $\mathrm{pH}$ values, they were similar in clarified and non-clarified beverages, although there was a slight tendency or a higher $\mathrm{pH}$ value for the beverages without clarification elaborated in treatment $\left(\mathrm{T}_{6}\right)$, but they were not significant.

Beverages made in the control treatment $\left(\mathrm{T}_{0}\right)$, maintained a constant $\mathrm{pH}$ over time with an average value of 6.27, which is similar to the values obtained by Hasani and Kongoli (s.a), where a pH of 6.43 in $100 \%$ wheatgrass juice was obtained. The rest of the treatments lowered their $\mathrm{pH}$, which is caused by the addition of $\mathrm{CO}_{2}$ and / or sweetener. Licata (s.a), indicates that $\mathrm{CO}_{2}$ produces a decrease of $\mathrm{pH}$, offering a bigger acidity to the beverage.

\section{Acidity}

The acidity found in the clarified and nonclarified beverages showed a degree of dispersion 
(Figure 2). According to Figure 2, it is possible to observe that the acid values showed their minimum value $(0.01 \%)$, in the beverages made in the control treatment $\left(\mathrm{T}_{0}\right)$ at 90 days of storage. The highest value $(0.30 \%)$ was obtained in the clarified beverages belonging to treatment $\left(\mathrm{T}_{5}\right)$ at 90 days of storage.

Statistical analysis showed that in the preparation of the beverage in the different treatments, plus the storage time, caused a statistically significant effect (p-value 0,000 ) on the acidity content, producing variations in all times of measurement. Regarding acidity values, they were similar for clarified and non-clarified beverages, although there was a slight tendency or a higher acid value in the non-clarified beverages elaborated in treatment $\left(\mathrm{T}_{2}\right)$, but it was not significant. The clarified beverages belonging to treatments $\left(T_{1}, T_{5}\right)$ and the beverages without clarification belonging to treatments $\left(\mathrm{T}_{2}, \mathrm{~T}_{6}\right)$ with $\mathrm{CO}_{2}$ added had the highest values of titratable acidity at all times of storage, being this in line with what was noted in the article written by Licata, (s.a), where it was stated that $\mathrm{CO}_{2}$ produces a $\mathrm{pH}$ decrease, bringing about a higher acidity to the beverage. The values obtained in this test, which were between 0.01 and $0.30 \%$, were similar to those obtained in the

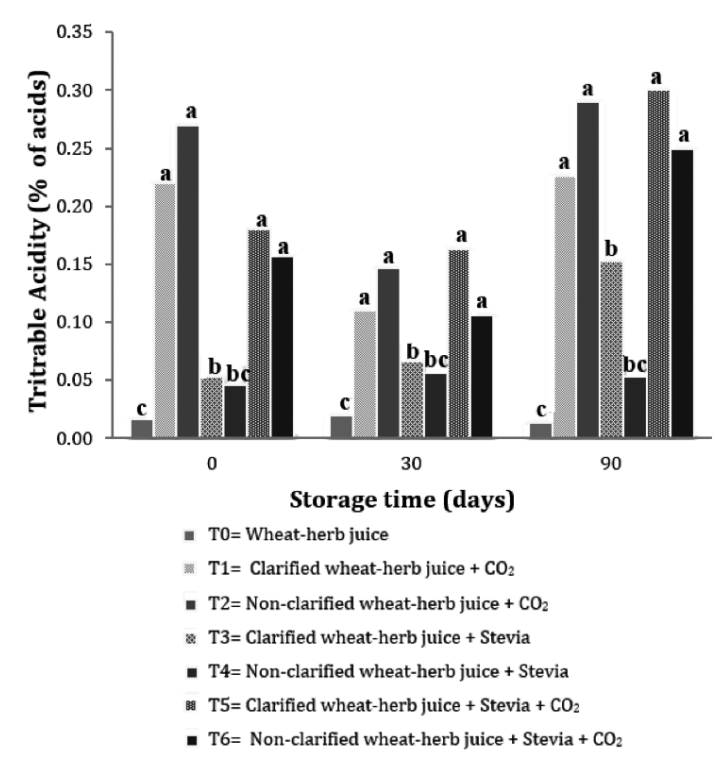

Figure 2. Average acidity (\%) equivalent to the acid in the wheatgrass juice evaluated on days 0,30 and 90 after being packaged and stored at $7^{\circ} \mathrm{C}$. * Different letters show statistically significant difference $(\alpha=0.05)$. acidity analysis of wheat grass or wheatgrass juice by Hasani and Kongoli (s.a), where an acidity value of $0.23 \%$ was obtained.

\section{Nutrition Analysis}

\section{Ascorbic acid}

The values of ascorbic acid or vitamin $\mathrm{C}$ showed a minimum $(9.6 \mathrm{mg} / 100 \mathrm{~g})$ in the non-clarified beverages belonging to treatment $\left(\mathrm{T}_{4}\right)$ at 90 days of storage. However, the highest concentration of ascorbic acid (23.2 mg / 100g) was obtained in the clarified beverages belonging to treatment $\left(\mathrm{T}_{3}\right)$ at 0 days of storage. The clarified beverages belonging to treatment $\left(\mathrm{T}_{1}\right)$ were the ones that remained more stable in regards to the values of concentration of ascorbic acid during the days of storage, considering that these values were changeable and decreased for the rest of the treatments in all moments of the research. Statistical analysis indicated that the preparation of the beverage under different treatments showed significant differences during the refrigerated storage time at $7^{\circ} \mathrm{C}$ (p-value 0.000$)$, indicating that the storage time, did influence on the content of vitamin C, but not for comparisons made among treatments (data not shown). Regarding the values of ascorbic acid or vitamin C, they were similar for clarified and non-clarified beverages, although there was a slight tendency or a higher value of ascorbic acid for the clarified beverages elaborated in treatment $\left(\mathrm{T}_{3}\right)$, but they were not significant (data not shown). The results obtained are similar to those described by Shukla et al., 2009, who obtained a value of $0.22 \mathrm{mg} / \mathrm{g}$ of vitamin $\mathrm{C}$ in powdered wheatgrass juice. Das et al., 2012, indicated that the content of ascorbic acid of fresh wheat grass decreased after the lyophilization process and kiln drying, because the drying process accelerates the oxidation of ascorbic acid. Gregory (1996) noted that in many sealed packages or food containers, degradation of ascorbic acid occurs through an oxidative and anaerobic via, especially in cans and bottles because of the presence of residual oxygen from the containers.

\section{Reducing sugars}

The values of reducing sugars found in clarified and non-clarified beverages showed a 
degree of dispersion (Figure 3). According to Figure 3, the values of reducing sugars showed their minimum value $(0.53 \%)$ in the non-clarified beverages belonging to treatment $\left(\mathrm{T}_{6}\right)$ at 90 days of storage. However, the highest concentration of reducing sugars $(0.98 \%)$ was obtained in the clarified beverages belonging to treatment $\left(\mathrm{T}_{5}\right)$ at 0 days of storage. It is important to highlight that in this analysis only traces of reducing sugars were observed. For the treatments in which these traces were observed during the storage time, they showed significant differences (p-value 0.000), which indicates that storage days somehow influenced the amount of sugars. In the beverages made in treatments $\left(\mathrm{T}_{0} ; \mathrm{T}_{1} ; \mathrm{T}_{2} ; \mathrm{T}_{3}\right)$, no traces of reducing sugar were observed in any storage time; in the beverages made in treatments $\left(\mathrm{T}_{4}\right.$ and $\left.\mathrm{T}_{5}\right)$, reducing sugar was observed only on day 0 of storage and only traces of reducing sugar were observed in all the beverages elaborated in treatment $\left(\mathrm{T}_{6}\right)$.

Traces of sugars were found in the clarified beverages belonging to treatment $\left(\mathrm{T}_{5}\right)$ and for the non-clarified beverages belonging to treatments $\left(T_{4}\right.$ and $\mathrm{T}_{6}$ ) at 0 days of storage, with values ranging from 0.68 to $0.98 \%$. At the 30 and 90 days of storage only traces of sugars were observed for the non-clarified beverages belonging to treatment $\left(\mathrm{T}_{6}\right)$, with values of $0.81 \%$ and $0.53 \%$, in each case.

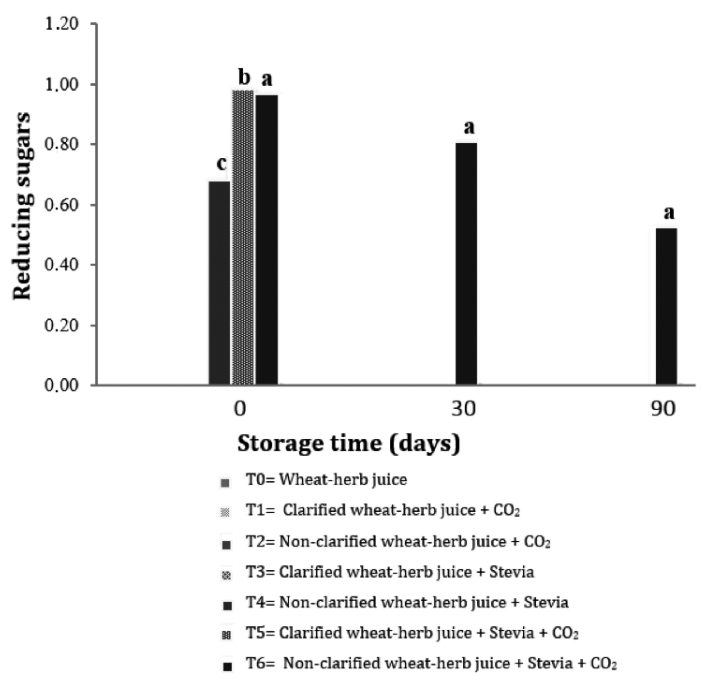

Figure 3. Average of reducing sugars $(\%)$ of the wheatgrass beverage evaluated on days 0,30 and 90 after being packaged and stored at $7{ }^{\circ} \mathrm{C}$.

* Different letters show statistically significant difference $(\alpha$ $=0.05$ ).
Regarding the content of reducing sugars, there was a significant difference among the juices prepared with and without clarification, this difference was due to treatments $\left(\mathrm{T}_{3}, \mathrm{~T}_{5}\right)$ in the case of the clarified ones and treatments $\left(\mathrm{T}_{4}, \mathrm{~T}_{6}\right)$ in the non-clarified ones, shown throughout the storage time. Sarma et al., 2015 obtained $1.67 \mathrm{~g} / 100 \mathrm{~mL}$ of reducing sugar in a wheat grass measurement, enriched by the addition of $2 \% \mathrm{D}$-glucose and saline solution and inoculated with the lactic acid bacterium Lactobacillus casei.

\section{Sensorial Analysis}

\section{Color}

The values of the color attribute, perceived by the panelists in clarified and non-clarified beverages at 90 days of storage showed a degree of dispersion (data not shown). The values of the color attribute showed their minimum (2.87) in clarified beverages belonging to treatment $\left(T_{1}\right)$. However, the highest value (4.33) was obtained in beverages made in the control treatment $\left(\mathrm{T}_{0}\right)$. The color detected in the beverage, according to the comparison of a color table adapted by Munsell (1994), showed values that were in the range of 2.87 to 4.33 . Statistical analysis showed that there was a significant difference among treatments (p-value 0.000), as a consequence, the different treatments had an implication in determining the "color" attribute by panelists. Regarding the values of the color attribute perceived by the panelists, this similarity of tendency or existence of the color attribute was given for clarified beverages made in treatments $\left(\mathrm{T}_{3}\right)$ and for non-clarified beverages elaborated in treatment $\left(\mathrm{T}_{4}\right)$.

\section{Aroma}

The values of the aroma attribute, perceived by the panelists in clarified and non-clarified beverages at 90 days of storage showed a degree of dispersion (data not shown). Beverages made in the control treatment $\left(\mathrm{T}_{0}\right)$ showed a value of (1.44), being the least evaluated according to the results obtained by the panelists. The clarified beverages belonging to treatment $\left(T_{5}\right)$ were the ones that showed a higher value in regards to the other treatments with (3.5). In general, it can be noted that the aroma rating by the panelists was 
in a "medium" range on a scale ranging from "no aroma" to "extremely aromatic", except for beverages made in the control treatment $\left(\mathrm{T}_{0}\right)$. The statistical analysis showed that there was a significant difference among treatments ( $\mathrm{p}$-value 0.001 ), as a consequence, the aroma attribute was influenced by the different treatments, according to the panelists' evaluation. By coincidence, the clarified beverages belonging to treatments $\left(\mathrm{T}_{3}\right.$ and $\mathrm{T}_{5}$ ) and the non-clarified ones belonging to treatments $\left(\mathrm{T}_{4}\right.$ and $\left.\mathrm{T}_{6}\right)$, which had stevia addition, had a higher evaluation by the panelists, approaching a "medium" on a scale ranging from "no aroma" to "extremely aromatic", which is not in line with the results obtained by (Quitral et al., 2015), who pointed out that the aroma of juices is not affected by the type of sweetener. In regards to the values of the aroma attribute perceived by the panelists, they were similar for clarified and non-clarified beverages, although there was a slight tendency or a higher selection of the aroma attribute for the clarified beverages elaborated in treatment $\left(\mathrm{T}_{5}\right)$, but they were not significant.

\section{Flavor}

The values of the taste attribute, perceived by the panelists for clarified and non-clarified beverages at 90 days of storage showed a degree of dispersion (Figure 4). According to Figure 4, beverages made in the control treatment $\left(\mathrm{T}_{0}\right)$ obtained a valuation of $(1,4)$, being the least valued according to the results obtained by the panelists, this fact locates it in the scale close to "acid". The clarified beverages belonging to treatment $\left(T_{5}\right)$ were the ones that showed a higher value with respect to the other treatments with a selection of $(4,5)$, a value in an average range on a scale ranging from "acid" to "very sweet".

Statistical analysis indicated that there was a significant difference among treatments (p-value 0.000), as a consequence, the different treatments influenced on the evaluation of the "flavor" attribute. This difference is due to the fact that beverages with clarification belonging to treatments $\left(\mathrm{T}_{3}\right.$ and $\left.\mathrm{T}_{5}\right)$ and beverages without clarification belonging to treatments $\left(\mathrm{T}_{4}\right.$ and $\left.\mathrm{T}_{6}\right)$ showed an addition of stevia, which locates them in a middle range of the scale, as perceived by the panelists. The judgments obtained by the panelists for the clarified beverages belonging

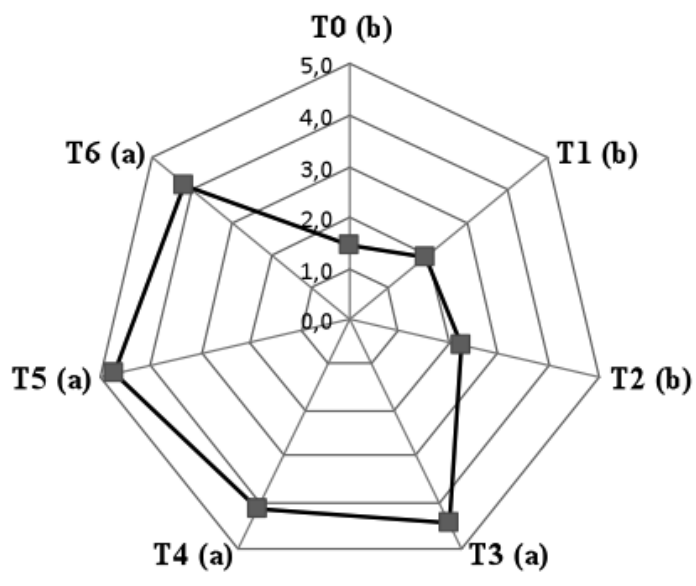

- $\mathrm{T} 0=$ Wheat-herb juice

in $\mathrm{T} 1=$ Clarified wheat-herb juice $+\mathrm{CO}_{2}$

- $\mathrm{T} 2=$ Non-clarified wheat-herb juice $+\mathrm{CO}_{2}$

: T3= Clarified wheat-herb juice + Stevia

- T4= Non-clarified wheat-herb juice + Stevia

明 $\mathrm{T}$ = Clarified wheat-herb juice + Stevia $+\mathrm{CO}_{2}$

- $\mathrm{T} 6=$ Non-clarified wheat-herb juice + Stevia $+\mathrm{CO}_{2}$

Figure 4. Average of the flavor parameter, belonging to the sensorial evaluation of the wheatgrass beverage evaluated at 90 days after being packaged and stored at $7{ }^{\circ} \mathrm{C}$.

* Different letters show statistically significant difference $(\alpha$ $=0.05$ ).

to treatment $\left(\mathrm{T}_{1}\right)$ and for beverages without clarification belonging to treatment $\left(\mathrm{T}_{2}\right)$, locates them in the scale close to "acid"; there is a coincidence between what it is said above and what was noted in an article by Licata (s.a), where he mentioned that $\mathrm{CO}_{2}$ produces a $\mathrm{pH}$ decrease and grants a bigger acidity to the beverages. Regarding the values of the taste attribute perceived by the panelists, they were similar for clarified and non-clarified beverages, although there was a slight tendency or a higher selection of the flavor attribute for the clarified beverages elaborated in treatment $\left(\mathrm{T}_{5}\right)$, but they were not significant.

\section{Acceptability}

The values of the acceptability attribute, perceived by the panelists for the clarified and non-clarified beverages at 90 days of storage showed a degree of dispersion (Figure 5). 


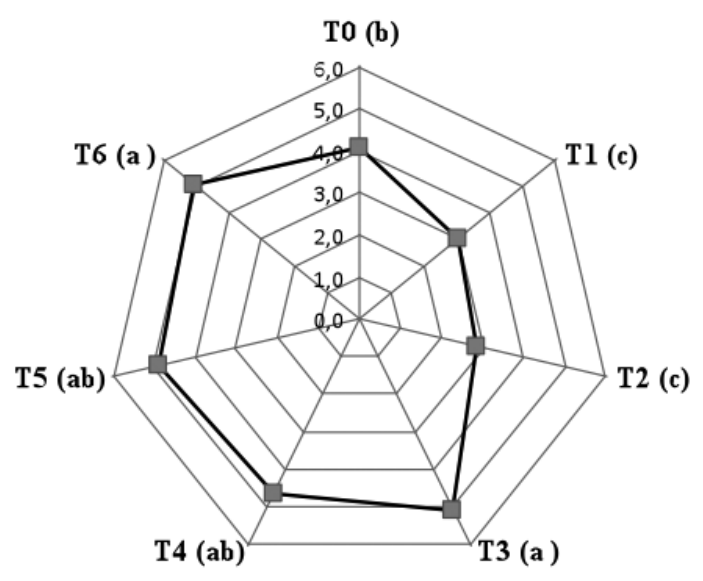

- $\mathrm{T} 0=$ Wheat-herb juice

in $\mathrm{T} 1=$ Clarified wheat-herb juice $+\mathrm{CO}_{2}$

- $\mathrm{T} 2=$ Non-clarified wheat-herb juice $+\mathrm{CO}_{2}$

* T3= Clarified wheat-herb juice + Stevia

- T4= Non-clarified wheat-herb juice + Stevia

T5= Clarified wheat-herb juice + Stevia $+\mathrm{CO}_{2}$

- $\mathrm{T} 6=$ Non-clarified wheat-herb juice + Stevia $+\mathrm{CO}_{2}$

Figure 5 . Average of the acceptability parameter belonging to the sensorial evaluation of the wheatgrass beverage evaluated at 90 days after being packaged and stored at $7{ }^{\circ} \mathrm{C}$.

* Different letters show statistically significant difference $(\alpha$ $=0.05$ ).

According to Figure 5, the clarified beverages belonging to treatment $\left(T_{2}\right)$ were the ones that showed a lower value with respect to the other treatments with a score of (2.8), value that locates them in the category "I moderately dislike it". The clarified beverages belonging to treatment $\left(\mathrm{T}_{3}\right)$ and the non-clarified beverages belonging to treatment $\left(\mathrm{T}_{6}\right)$ were the ones that showed a higher evaluation by the panelists, with respect to the other treatments with a score of (5.1), a value that locates them in the category "I neither like it nor I dislike it", on a scale that ranges from 1 to 9, categories that belong to "I extremely dislike it" and "I extremely like", in each case. The acceptability of wheatgrass beverages, after 90 days of processing, showed significant differences among treatments, (p-value 0.000), indicating that the elaboration in each treatment influenced on the parameter evaluated. The difference obtained was not significant in relation to the clarified beverages, the panelists perceived the highest acceptability with a value of $(5,1)$, which belongs to "I neither like it nor I dislike it", which was associated with treatment $\left(\mathrm{T}_{3}\right)$. Regarding non-clarified beverages, panelists presented the maximum acceptability value $(5,1)$, belonging to "I neither like it nor dislike it", being associated with treatment $\left(\mathrm{T}_{6}\right)$.

\section{Total coliform count and Escherichia coli}

Total coliforms and Escherichia coli are indicators of health in processed beverages which, according to what is regulated by the Chilean Ministry of Health, require a value of <3 NMP / $\mathrm{g}$ to guarantee the safety of these products; this requirement has been fulfilled in all processed beverages (Table 3 and 4).

"If the presence of pathogenic microorganisms not listed in the list below is detected in a food, the health authority may consider it as a contaminated food, according to the evaluation of the risks arising from its presence".

Table 3. Maximum limit of pathogenic microorganisms in carbonated and alcoholic beverages.

\begin{tabular}{|c|c|c|c|c|c|c|}
\hline \multirow{2}{*}{ Parameter } & \multicolumn{3}{|c|}{ Sampling Plan } & \multicolumn{2}{|c|}{$\begin{array}{l}\text { Limit } \\
\text { per ml }\end{array}$} & \multirow{2}{*}{ M } \\
\hline & Category & Class & $\mathrm{n}$ & $\mathrm{c}$ & $\mathrm{m}$ & \\
\hline Yeasts & 3 & 3 & 5 & 1 & 1 & 10 \\
\hline
\end{tabular}

Source: Ministry of Health of Chile, 2015.

Table 4. Maximum limit of pathogenic microorganisms in mineral waters and bottled waters.

\begin{tabular}{lccccccc}
\hline \multirow{2}{*}{\multicolumn{1}{c}{ Parameter }} & \multicolumn{3}{c}{ Sampling Plan } & \multicolumn{4}{c}{$\begin{array}{c}\text { Limit } \\
\text { per ml }\end{array}$} \\
\cline { 2 - 5 } & Category & Class & $\mathrm{n}$ & $\mathrm{c}$ & $\mathrm{m}$ & \\
\hline Aerobic Rct. Mesóf. & 3 & 3 & 5 & 2 & 25 & 102 \\
E. Coli in $100 \mathrm{ml}$ & 10 & 2 & 5 & 0 & 0 & - \\
\hline
\end{tabular}

Source: Ministry of Health of Chile, 2015.

\section{Conclusions}

The hypothesis drawn has been fulfilled in relation to the fact that it has been possible to produce clarified and non-clarified beverages from wheatgrass juice by adding stevia and a $\mathrm{CO}_{2}$ injection. 
Clarified and non-clarified beverages from wheatgrass juice plus stevia with a $\mathrm{CO}_{2}$ injection showed a similar content of vitamin $\mathrm{C}$, acidity and $\mathrm{pH}$.

Clarified and non-clarified beverages from wheatgrass juice plus stevia with a $\mathrm{CO}_{2}$ injection had significantly different contents of soluble solids and reducing sugars.
Clarified and non-clarified beverages from wheatgrass juice plus stevia with a $\mathrm{CO}_{2}$ injection showed a similar perception of the sensorial attributes color, aroma and flavor, as well as an equal degree of acceptability by panelists.

The number of microorganisms, total coliforms and Escherichia coli was lower than the range permitted by the Chilean food regulations.

\section{Literature Cited}

Association of Official Analytical A.O.A.C. 1990. Official Methods of Analysis. 1298 p.

Das, A; Raychaudhuri, U.; Chakraborty R.

2012. Effect of freeze-drying and oven drying on antioxidant properties of fresh wheatgrass. International Journal of Food Sciences and Nutrition, 63 (6): 718-721.

Food and Agriculture Organization of the United Nations FAO. 1993. Procesamiento de frutas y hortalizas mediante métodos artesanales y de pequeña escala. Oficina regional de la FAO para américa latina y el caribe. Santiago, Chile. 190 p.

Gregory, J.

1996. Vitamins. En: Dekker, M. Food Chemistry. Madison. Food science and technology. Wisconsin, USA. pp. 531-616.

Hasani, A.; Kongoli, R.

Análisis sensorial de aceptación del consumidor y el jugo de pasto de trigo Extracción de Rendimiento, hierba de cebada y avena Grass Zumos. Revista Internacional de Investigación Innovadora en Ciencias e Ingeniería ISSN, 3 (12): 407.

Hernández, E.

2005. Evaluación sensorial. UNAD. Bogotá, Colombia. 125 p.

Instituto de Políticas Públicas en Salud IPSUSS.

Bebidas azucaradas, más que un simple refresco. Disponible en: http://www.ipsuss.cl/ipsuss/analisis-y-estudios/ obesidad/bebidas-azucaradas-mas-que-un-simplerefresco/2014-10-23/174005.html Consultado: 11/nov/2019.

Licata, M.

Las bebidas gaseosas, composición y características de sus ingredientes. Disponible en: http://www.zonadiet.com/ bebidas/bebidasgaseosas.htm: Consultado: 02/jun/2016.

Ministerio de Salud de Chile.

2015. Artículo 173: Título V De los criterios microbiológicos. Reglamento sanitario de los alimentos dto. N $\mathrm{N}^{\mathrm{o}}$ 977/96. Enero, 2015. 182 p.
Moreno, I; Ramírez, A; Plana, R; Iglesias L.

2001. El cultivo del trigo. algunos resultados de su producción en Cuba. Instituto Nacional de Ciencias Agrícolas. 22(4): 55-67.

Munsell Color Co.

1994. Munsell Soil Color Charts. U.S. Dept. Agriculture Handbook 18-Soil Survey Manual. New York, USA. 29 p.

Quitral, V; Pinheiro, A; Carrera, C; Gallo, Gabriela; Moyano,

P; Salinas, J.; Jiménez, P.

2015. Efecto de edulcorantes no calóricos en la calidad sensorial de jugo de naranja. Revista chilena de nutrición, 42 (1): 77-82

Santibáñez, F.Q.; Uribe, J.M.

1993. Atlas agroclimático de chile: Regiones sexta, séptima, octava y novena. Colaborador, Universidad de Chile. Departamento de ingeniería y suelos. Ministerio de agricultura, fondo de investigación agropecuaria. 99 p.

Sarma, G.; Bakshi,G.; Metha, S.; Oommen, S.; Subnani, T.

2015. Suitability of certain non-dairy food substances processed by lactic acid fermentation for applications as probiotics. World journal of pharmacy and pharmaceutical science, 4 (1): 1563-1570.

Shukla, V.; Vashistha, M.; Singh S.

2009. Evaluation of antioxidant profile and activity of amalaki (Emblica officinalis), spirulina and wheat grass. Indian Journal of Clinical Biochemistry, 24 (1): 70-75.

Wakeham, P.

2013. The medicinal and pharmacological screening of wheatgrass juice (Triticum aestivum L.): an investigation into chlorophyll content and antimicrobial activity. The Plymouth Student Scientist, 6 (2): 20-30.

Zapata, L.

2011. Bebida de fantasía (gaseosa del tipo cola). Organización de consumidores y usuarios de Chile. Santiago, Chile. 31 p. 
